\title{
PENGARUH CORPORATE GOVERNANCE, PROFITABILITAS DAN KARAKTER EKSEKUTIF TERHADAP TAX AVOIDANCE PADA PERUSAHAAN YANG TERDAFTAR DI BEI
}

\author{
Muhammad Fajri Saputra \\ Universitas Bung Hatta \\ e-mail: fajri_cold@yahoo.com \\ Dandes Rifa \\ Universitas Bung Hatta \\ e-mail: dandesrifaziohr@gmail.com \\ Novia Rahmawati \\ Universitas Bung Hatta \\ e-mail: noviarahma_titi@yahoo.com
}

\begin{abstract}
This study aims to determine the effect of corporate governance, profitability, and executive character to the activity of tax avoidance in companies listed on the Indonesia Stock Exchange in 2012-2014. The elements of corporate governance consists of a proportion of the independent board, audit quality and audit committee as well as the elements of profitability is return on assets and the last variable is an executive character. The samples are property, real estate, and building construction companies are listed on the Indonesia Stock Exchange 2012-2014. The samples obtained 38 companies were selected by using purposive sampling. Data analysis was performed by hypothesis testing is multiple regression. The results show that the elements of corporate governance, namely the proportion of independent board, audit quality and audit committee did not significantly effect on activity of tax avoidance. While the return on assets and executive character are significantly effect on activity of tax avoidance.
\end{abstract}

Keywords: corporate governance, the proportion of independent board, the quality audit, the audit committee, profitability, return on assets, executive character http://dx.doi.org/10.20885/jaai.vol19.iss1.art1

\begin{abstract}
Abstrak
Penelitian ini bertujuan untuk menentukan pengaruh corporate governance, profitabilitas, dan karakter eksekutif terhadap tax avoidance di perusahaan yang terdaftar di Bursa Efek Indonesia tahun 2012-2014. Elemen dari corporate governance berisi proporsi dewan, kualitas audit, dan audit komite, sedangkan profitabilitas berisi return on assets dan karakter eksekutif. Sampel penelitian ini adalah perusahaan properti, real estate, dan building construction yang terdaftar di Bursa Efek Indonesia tahun 2012-2014. Sampel yang dibangun adalah 38 perusahaan yang dipilih dengan purposive sampling. Analisis data menggunakan multiple regression untuk menguji hipotesis. Hasil menunjukkan bahwa proporsi dewan, kualitas audit, dan audit komite tidak signifikan mempengaruhi tax avoidance. Sementara itu, return on assets dan karakter eksekutif signifikan mempengaruhi tax avoidance.
\end{abstract}

Kata kunci: corporate governance, proporsi dewan independen, kualitas audit, komite audit, profitabilitas, return on asset, karakter eksekutif

\section{PENDAHULUAN}

Pajak merupakan salah satu sumber penerimaan negara yang paling besar. Dengan demi- kian sangat diharapkan kepatuhan wajib pajak dalam menjalankan kewajiban perpajakannya secara sukarela sesuai dengan peraturan per- 
pajakan yang berlaku. Ketidakpatuhan wajib pajak masih sering kita dengar dewasa ini. Salah satu ketidakpatuhan pajak yang dilakukan wajib pajak adalah penghindaran pajak ( tax avoidance), yaitu upaya pengurangan beban pajak secara legal yang tidak melanggar peraturan perpajakan yang dilakukan wajib pajak dengan cara berusaha mengurangi jumlah pajak terutangnya dengan mencari kelemahan peraturan (loopholes) (Dewi dan Jati 2014).

Tax avoidance yang dilakukan ini dikatakan tidak bertentangan dengan peraturan perundang-undangan tentang perpajakan, karena dianggap praktik yang berhubungan dengan tax avoidance ini lebih memanfaatkan celah-celah dalam undang-undang perpajakan tersebut yang akan mempengaruhi penerimaan dari sektor pajak (Mangoting 1999). Tetapi praktik tax avoidance ini tidak selalu dapat dilaksanakan, karena wajib pajak tidak selalu bisa menghindari semua unsur atau fakta yang dikenakan (Dewi dan Jati 2014).

Penelitian ini juga termotivasi oleh maraknya kasus penghindaran pajak di Indonesia yang dilakukan oleh perusahaanperusahaan multinasional (multinational corporations) yang beroperasi di Indonesia menggunakan skema-skema penghindaran pajak yang merugikan baik negara asal maupun negara tujuan investasi (Dirjen Pajak 2014).

Salah satu contoh kasus di Indonesia adalah kasus simulator SIM, dimana ada penjualan rumah mewah oleh developer kepada terdakwa, seharga Rp 7,1 milyar di Semarang. Namun di akta notaris, hanya tertulis Rp 940 juta atau ada selisih harga Rp 6,1 milyar. Atas transaksi ini, ada potensi PPN (Pajak Pertambahan Nilai) yang harus disetor 10 persen dikali $\mathrm{Rp} 6,1$ milyar atau $\mathrm{Rp} 610$ juta. Kekurangan lain PPh (Pajak Penghasilan) final sebesar 5 persen dikalikan Rp 6,1 milyar atau Rp 300 juta. Total kekurangan pajak senilai Rp 900 juta. Jika developer ini menjual ratusan unit rumah mewah, kerugian negara bisa mencapai puluhan milyar rupiah dari satu proyek perumahan (pajak.go.id).

Corporate governance (CG) merupakan tata kelola perusahaan yang menjelaskan hubungan antara berbagai partisipan dalam perusahaan yang menentukan arah kinerja perusahaan. Banyaknya perusahaan yang melakukan penghindaran pajak membuktikan bahwa CG belum sepenuhnya dilakukan oleh perusahaan-perusahaan publik Indonesia (Maharani dan Suardana 2014). Proksi dari CG yang digunakan dalam penelitian ini adalah proporsi dewan komisari independen, kualitas audit dan komite audit. Profitabilitas merupakan salah satu pengukuran bagi kinerja suatu perusahaan. Profitabilitas suatu perusahaan menggambarkan kemampuan suatu perusahaan dalam menghasilkan laba selama periode tertentu pada tingkat penjualan, asset dan modal saham tertentu.

Profitabilitas terdiri dari beberapa rasio, salah satunya adalah return on assets (ROA). ROA adalah suatu indikator yang mencerminkan performa keuangan perusahaan, semakin tingginya nilai ROA yang mampu diraih oleh perusahaan maka performa keuangan perusahaan tersebut dapat dikategorikan baik. ROA dilihat dari laba bersih perusahaan dan pengenaan Pajak Penghasilan (PPh) untuk wajib pajak badan. ROA adalah rasio keuntungan bersih pajak yang juga berarti suatu ukuran untuk menilai seberapa besar tingkat pengembalian dari aset yang dimiliki perusahaan. Perusahaan yang memperoleh laba diasumsikan tidak melakukan tax avoidance karena mampu mengatur pendapatan dan pembayaran pajaknya (Maharani dan Suardana 2014).

Penghindaran pajak yang dilakukan perusahaan tentu saja melalui kebijakan yang diambil oleh pemimpin perusahaan itu sendiri. Dimana pimpinan perusahaan sebagai pengambil keputusan dan kebijakan dalam perusahaan sebagai pengambil keputusan dan kebijakan dalam perusahaan tentu memiliki karakter yang berbeda-beda. Seorang pemimpin perusahaan bisa saja memiliki karakter risk taker atau risk averse yang tercermin dari besar kecilnya risiko perusahaan (Budiman dan Setioyono 2012). Pemimpin perusahaan yang bersifat risk taker akan cenderung lebih berani dalam mengambil keputusan walaupun keputusan tersebut berisiko tinggi. Selain itu pemilik karakter ini juga tidak ragu dalam melakukan pembiayaan yang 
berasal dari hutang untuk pertumbuhan perusahaan yang lebih cepat(Lewellen 2006).

Penelitian ini dilakukan untuk meneliti pengaruh CG dilihat dari segi proporsi dewan komisaris independen, kualitas audit, dan komite audit, serta return on assets dan karakter eksekutif terhadap penghindaran pajak (tax avoidance).

\section{TINJAUAN PUSTAKA DAN PERUMUSAN HIPOTESIS}

\section{Tax (Pajak)}

Pajak merupakan salah satu sumber penerimaan negara yang paling besar. Salah satu usaha untuk mewujudkan kemandirian suatu bangsa dan negara dalam pembiayaan pembangunan yaitu menggali sumber dana yang berasal dari dalam negeri berupa pajak. Pajak digunakan untuk membiayai pembangunan yang berguna bagi kepentingan bersama. Pajak adalah iuran kepada negara (yang dapat dipaksakan) yang terutang oleh yang wajib membayarnya menurut peraturan-peraturan, dengan tidak mendapat prestasi kembali, yang langsung dapat ditunjuk, dan yang gunanya adalah untuk membiayai pengeluaranpengeluaran umum berhubung dengan tugas negara yang menyelenggarakan pemerintahan (Waluyo 2011).

\section{Tax Avoidance (Penghindaran Pajak)}

Hutagaol (2007) menyebutkan bahwa tax avoidance yaitu upaya penghindaran pajak secara legal yang tidak melanggar peraturan perpajakan yang dilakukan wajib pajak dengan cara berusaha mengurangi jumlah pajak terutangnya dengan mencari kelemahan (loopholes).

\section{Agency Theory}

Menurut Jensen and Meckling (1976), agency theory merupakan perspektif yang secara jelas menggambarkan masalah yang timbul dengan adanya pemisahan antara kepemilikan dan pengendalian terhadap perusahaan, yaitu terdapatnya konflik kepentingan dalam perusahaan.

Meilinda dan Cahyonowati (2013) menyatakan bahwa masalah yang terjadi antara manajemen dan pemilik modal menyebabkan munculnya biaya. Dan disinilah letak pentingnya CG. Jensen dan Meckling (1976) menyatakan bahwa agency cost terdiri atas monitoring cost dan bonding cost. Bonding cost merupakan agency cost yang ditanggung oleh direksi yang mencerminkan upaya manajemen dalam menunjukkan kepada shareholder bahwa mereka tidak akan menyalahgunakan wewenang yang diberikan.

\section{Corporate Governance (CG)}

CG menurut Komite Nasional Kebijakan Governance (KNKG) adalah salah satu pilar dari sistem ekonomi pasar. CG berkaitan erat dengan kepercayaan baik terhadap perusahaan yang melaksanakannya maupun terhadap iklim usaha yang kondusif (Annisa dan Kurniasih 2012). Menurut Desai (2005), CG secara definitif merupakan sistem yang mengatur dan mengendalikan perusahaan untuk menciptakan nilai tambah (value added) untuk semua stockholder. Secara singkat, ada empat komponen utama yang diperlukan dalam konsep CG ini, yaitu fairness, transparency, accountability, dan responsibility.

\section{Proporsi Dewan Komisaris Independen}

Komisaris independen didefinisikan sebagai seorang yang tidak terafiliasi dalam segala hal dengan pemegang saham pengendali, tidak memiliki hubungan afiliasi dengan dewan direksi atau dewan komisaris serta tidak menjabat sebagai direktur pada suatu perusahaan terkait dengan perusahaan pemilik menurut peraturan yang dikeluarkan oleh BEI, jumlah komisaris independen proporsional dengan jumlah saham yang dimiliki oleh pemegang saham yang tidak berperan sebagai pengendali dengan ketentuan jumlah komisaris independen sekurang-kurangnya tiga puluh persen $(30 \%)$ dari seluruh anggota komisaris, disamping hal itu komisaris independen memahami undang-undang dan peaturan tentang pasar modal serta diusulkan oleh pemegang saham yang bukan merupakan pemegang saham pengendali dalam Rapat Umum Pemegang Saham (RUPS) (Pohan 2009). 


\section{Kualitas Audit}

Kualitas audit adalah segala kemungkinan yang dapat terjadi saat auditor mengaudit laporan keuangan klien dan menemukan pelanggaran atau kesalahan yang terjadi, dan melaporkannya dalam laporan keuangan auditan (Maharani dan Suardana 2014). Laporan keuangan yang diaudit oleh auditor KAP The Big Four menurut beberapa referensi dipercaya lebih berkualitas sehingga menampilkan nilai perusahaan yang sebenarnya, oleh karena itu diduga perusahaan yang diaudit oleh KAP The Big Four memiliki tingkat kecurangan yang lebih rendah dibandingkan dengan perusahaan yang diaudit oleh KAP non The Big Four (Annisa dan Kurniasih 2012).

\section{Komite Audit}

Winata (2014) menyebutkan komite audit adalah sekumpulan orang yang dipilih dari anggota dewan komisaris yang bertanggung jawab untuk mengawasi proses pelaporan keuangan dan pengungkapan (disclosure). Komite audit memiliki peran penting sebagai salah satu organ perusahaan yang mutlak harus ada dalam penerapan CG.

\section{Profitabilitas}

Tujuan utama perusahaan adalah memperoleh laba sebesar-besarnya. Rasio profitabilitas merupakan rasio untuk menilai kemampuan perusahaan dalam mencari keuntungan. Rasio ini juga memberikan ukuran tingkat efektifitas manajemen suatu perusahaan.

\section{Return on Assets (ROA)}

ROA adalah suatu indikator yang mencerminkan performa keuangan perusahaan, semakin tinggi nilai ROA yang mampu diraih oleh perusahaan maka performa keuangan perusahaan tersebut dapat dikategorikan baik. Perusahaan yang memperoleh laba diasumsikan tidak melakukan tax avoidance karena mampu mengatur pendapatan dan pembayaran pajaknya (Maharani dan Suardana 2014).

\section{Karakter Eksekutif}

Low (2009) menyebutkan bahwa dalam menjalankan tugasnya sebagai pimpinan perusa- haan eksekutif memiliki dua karakter yakni sebagai risk taker dan risk averse. Eksekutif yang memiliki karakter risk taker adalah eksekutif yang lebih berani dalam mengambil keputusan bisnis dan biasanya memiliki dorongan kuat untuk memiliki penghasilan, posisi, kesejahteraan, dan kewenangan yang lebih tinggi. Eksekutif yang memiliki karakter risk taker tidak ragu-ragu untuk melakukan pembiayaan hutang (Lewellen 2006).

\section{Pengaruh Proporsi Dewan Komisaris Terhadap Tax Avoidance}

Pada penelitian sebelumnya Dewi dan Jati (2014) menyebutkan terdapat pengaruh signifikan antara proporsi dewan komisaris terhadap tax avoidance, ini berarti keberadaan dewan komisaris independen efektif dalam usaha mencegah tindakan penghindaran pajak. Hasil yang sama dengan penelitian Prakosa (2014), komisaris independen yang merupakan bagian dari dewan komisaris melakukan fungsi pengawasan yang cukup baik terhadap manajemen perusahaan dan dapat mencegah terjadinya penghindaran pajak.

Begitu juga Maharani dan Suardana (2014), keberadaan dewan komisaris independen efektif dalam pencegahan penghindaran pajak. Dan juga Pranata (2014) yang menyatakan bahwa terdapat pengaruh antara proporsi dewan komisaris terhadap tax avoidance. Berbeda dengan penelitian yang dilakukan Annisa dan Kurniasih (2012) yang menyebutkan proporsi dewan komisaris independen tidak berpengaruh terhadap tax avoidance, hal itu disebabkan dewan komisaris independen yang berasal dari luar perusahaan menuntut manajemen bekerja lebih efektif dalam pengawasan dan pengendalian pengelolaan perusahaan oleh direksi dan manajer, sehingga keberadaan mereka tidak hanya symbol semata.

$\mathrm{H}_{1}$ : Corporate Governance yang dilihat dari proporsi dewan komisaris berpengaruh terhadap tax avoidance.

\section{Pengaruh Kualitas Audit Terhadap Tax Avoidance}

Menurut Annisa dan Kurniasih (2012), apabila suatu perusahaan diaudit oleh KAP The Big Four akan sulit melakukan kebijakan pajak 
agresif. Sejalan dengan Maharani dan Suardana (2014) dan Dewi dan Jati (2014), kualitas audit yang tinggi dapat mengurangi praktik pengindaran pajak. Perusahaan yang diaudit oleh KAP The Big Four lebih kompeten dan profesional dibandingkan dengan auditor yang termasuk dalam KAP non The Big Four, sehingga memiliki pengetahuan yang lebih banyak tentang cara mendeteksi dan memanipulasi laporan keuangan yang mungkin dilakukan oleh perusahaan. Oleh karena itu terdapat pengaruh kualitas audit terhadap tax avoidance.

Berbeda dengan penelitian Pranata (2014), kualitas audit tidak berpengaruh terhadap tax avoidance sebab perusahaan yang diaudit oleh KAP The Big Four belum tentu dapat mengurangi praktik penghindaran pajak. $\mathrm{H}_{2}$ : Corporate Governance yang dilihat dari kualitas audit berpengaruh terhadap tax avoidance.

\section{Pengaruh Komite Audit Terhadap Tax Avoidance}

Dalam penelitian Dewi dan Jati (2014) menyebutkan bahwa semakin tinggi keberadaan komite audit dalam perusahaan akan meningkatkan CG di dalam perusahaan, sehingga akan memperkecil kemungkinan praktik penghindaran pajak yang dilakukan.

Berbeda dengan penelitian Prakosa (2014), komite audit yang merupakan bagian dari perseroan mempunyai tugas untuk melakukan pengawasan dan pengevaluasian terhadap kinerja operasional perusahaan tidak berjalan dengan baik.

$\mathrm{H}_{3}$ : Corporate Governance yang dilihat dari komite audit berpengaruh terhadap tax avoidance.

\section{Pengaruh Return on Assets Terhadap Tax Avoidance}

Dalam penelitian Maharani dan Suardana (2014) menyebutkan bahwa perusahaan yang memperoleh laba diasumsikan tidak melakukan tax avoidance karena mampu mengatur pendapatan dan pembayaran pajaknya. Prakosa (2014) dalam penelitiannya juga menyebutkan jika ROA mengalami peningkatan, maka penghindaran pajak akan mengalami penurunan.

$\mathrm{H}_{4}$ : Return on Assets berpengaruh terhadap tax avoidance.

\section{Pengaruh Karakter Eksekutif Terhadap Tax Avoidance}

Penelitian yang dilakukan oleh Dyreng, Hanlon, dan Maydew (2010) menyebutkan bahwa pimpinan perusahaan (executive) secara individu memiliki peran yang signifikan terhadap tingkat penghindaran pajak perusahaan. Budiman dan Setiyono (2012) dalam penelitiannya berhasil membuktikkan bahwa semakin eksekutif bersifat risk taker maka akan semakin tinggi tingkat penghindaran pajak. Hal ini menunjukkan bahwa risiko perusahaan memiliki pengaruh signifikan terhadap tax avoidance. Sependapat dengan Maharani dan Suardana (2014) dan Dewi dan Jati (2014), eksekutif yang semakin bersifat risk taker kemungkinan akan lebih besar melakukan tindakan tax avoidance. Tingkat risiko perusahaan yang besar mengindikasikan bahwa pimpinan perusahaan lebih bersifat risk taker yang lebih berani mengambil risiko.

$\mathrm{H}_{5}$ : Karakter eksekutif berpengaruh terhadap tax avoidance.

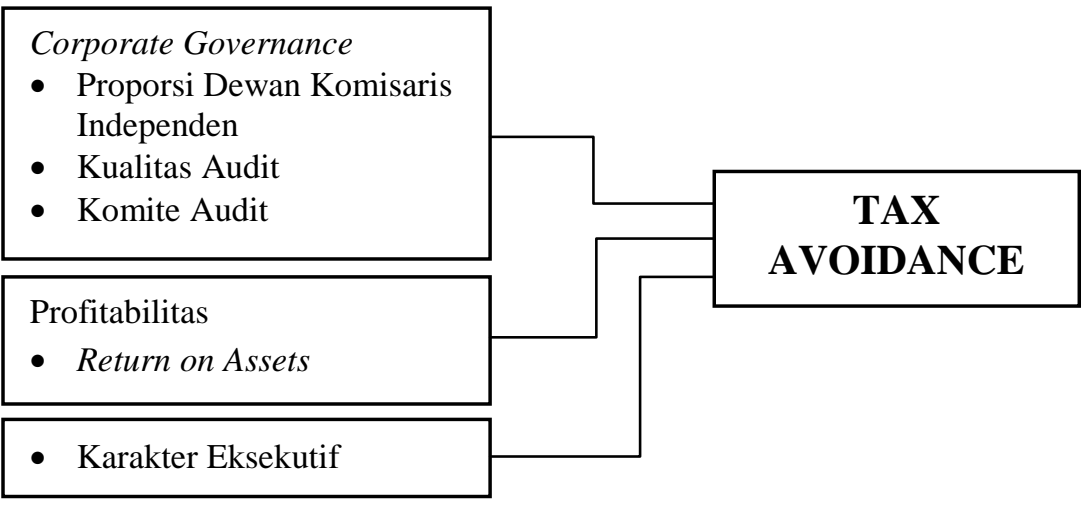

Gambar 1: Kerangka Penelitian 


\section{METODA PENELITIAN}

\section{Populasi dan Sampel}

Populasi adalah wilayah generalisasi yang terdiri atas objek atau subjek yang memiliki kualitas dan karakteristik tertentu yang diterapkan oleh peneliti untuk dipelajari dan kemudian ditarik kesimpulannya (Sugiyono 2013). Populasi dalam penelitian ini adalah perusahaan property, real estate, dan building construction yang terdaftar dan menawarkan sahamnya pada Bursa Efek Indonesia. Sampel adalah subset atau subkelompok populasi (Sekaran 2011). Sampel dipilih dengan menggunakan metode purposive sampling dengan kriteria sebagai berikut: 1) Perusahaan property, real estate, dan building construction yang terdaftar di Bursa Efek Indonesia selama tiga tahun yaitu tahun 2012-2014 dan tidak mengalami delisting selama periode pengamatan. 2) Perusahaan memuat dan mempublikasikan laporan keuangan yang berakhir tanggal 31 Desember periode 2012-2014. 3) Perusahaan property, real estate, dan building construction yang tidak mengalami rugi pada laba sebelum pajak periode 2012-2014. 4) Perusahaan yang memiliki data mengenai komisaris independen, kualitas audit, dan komite audit yang diperlukan untuk penelitian.

\section{Jenis dan Sumber Data}

Jenis data dalam penelitian ini yaitu data sekunder berupa laporan tahunan perusahaan yang terdaftar di Bursa Efek Indonesia selama tahun 2012-2014. Sumber data diperoleh website resmi perusahaan dan website resmi Bursa Efek Indonesia.

\section{Definisi dan Pengukuran Variabel}

\section{Variabel Dependen}

Variabel Dependen merupakan variabel yang terikat dan variabel yang dipengaruhi oleh variabel lainnya.

\section{Tax Avoidance}

Variabel dependen yang digunakan dalam penelitian ini yaitu tax avoidance. Tax avoidance yaitu merupakan usaha pengurangan bahkan meniadakan hutang pajak yang harus dibayar perusahaan dengan cara legal atau tidak melanggar undang-undang yang ada dengan memanfaatkan kelemahan peraturan perpajakan di suatu Negara. Seperti penelitian yang dilakukan peneliti sebelumnya, variabel ini juga diproksikan dengan menggunakan rumus Tarif Pajak Efektif (ETR). Tarif Pajak Efektif digunakan sebagai pengukuran karena dianggap dapat merefleksikan perbedaan tetap antara perbedaan laba buku dan laba fiskal.

Tarif Pajak Efektif dihitung dengan menggunakan cara membagi total beban pajak perusahaan dengan laba sebelum pajak penghasilan:

$$
\mathrm{ETR}=\frac{\text { Beban Pajak }}{\text { Laba Sebelum Pajak }}
$$

\section{Variabel Independen}

Variabel independen merupakan variabel yang diproyeksikan mempengaruhi variabel lain (variabel dependen). Dalam penelitian ini penulis menggunakan beberapa variabel independen antara lain sebagai berikut:

\section{Proporsi dewan komisaris independen}

Komisaris independen didefinisikan sebagai seorang yang tidak terafiliasi dalam segala hal dengan pemegang saham pengendali. Proporsi dewan komisaris independen diukur menggunakan presentase jumlah dewan komisaris independen terhadap jumlah total komisaris dalam susunan dewan komisaris perusahaan sampel tahun amatan. Proporsi Dewan Komisaris Independen dilambangkan dengan PDKI.

\section{Kualitas audit}

Kualitas audit adalah segala kemungkinan yang dapat terjadi saat auditor mengaudit laporan keuangan klien dan menemukan pelanggaran atau kesalahan yang terjadi, dan melaporkannya dalam laporan keuangan auditan (Maharani dan Suardana 2014). Kualitas audit diukur dengan menggunakan variabel dummy yaitu perusahaan yang diaudit oleh Big Four ditandai dengan angka 1 dan yang diaudit oleh non Big Four ditandai dengan 
angka 0 . Variabel kualitas audit dilambangkan dengan KLT.

\section{Komite audit}

Pranata (2014) menyebutkan komite audit adalah sekumpulan orang yang dipilih dari anggota dewan komirasis yang bertanggung jawab untuk mengawasi proses pelaporan keuangan dan pengungkapan (disclosure). Dalam penelitian ini digunakan jumlah komite audit dalam suatu perusahaan dikali seratus persen (100\%) sebagai alat ukur. Variabel komite audit dilambangkan dengan KMT.

\section{Return on Assets (ROA)}

ROA menggambarkan kemampuan manajemen untuk memperoleh keuntungan (laba). Semakin tinggi ROA, semakin tinggi keuntungan perusahaan sehingga semakin baik pengelolaan aktiva perusahaan. ROA dalam penelitian ini menggunakan rumus sebagai berikut:

$$
\mathrm{ROA}=\frac{\text { Laba Rugi Bersih Setelah Pajak }}{\text { Total Asset }} \times 100 \%
$$

\section{Karakter Eksekutif}

Low (2009) menyebutkan bahwa, dalam menjalankan tugasnya sebagai pimpinan perusahaan eksekutif memiliki dua karakter yakni sebagai risk taker dan risk averse. Eksekutif yang memiliki karakter risk taker adalah eksekutif yang lebih berani dalam mengambil keputusan bisnis dan biasanya memiliki dorongan kuat untuk memiliki penghasilan, posisi, kesejahteraan, dan kewenangan yang lebih tinggi. Untuk mengukur resiko perusahaan ini dihitung melalui deviasi standar dari EBITDA (Earning Before Income Tax, Depreciation, and Amortization) dibagi dengan total asset perusahaan. Rumus deviasi standar tersebut adalah sebagai berikut:

$$
R I S K=\overline{\sum_{T-1}^{T}\left(E-1 / T \sum_{T-1}^{T} E\right)^{2} /(T-1)}
$$

Dimana E adalah EBITDA dibagi dengan total asset dari perusahaan.

\section{Metode Analisa Data}

Dalam melaksanakan pengujian statistik, maka penulis melakukan pengujian data yang digunakan dalam penelitian ini dengan menggunakan tahapan pengujian meliputi analisis deskriptif statistic, uji asumsi klasik yang terdiri dari uji normalitas, multikolineritas, heteroskedastisitas dan autokorelasi. Selanjutnya analisa regresi linear berganda, kemudian pengujian hipotesis menggunakan uji koefisien determinasi $\left(\mathrm{R}^{2}\right)$, uji f statistik dan uji t statistik.

\section{HASIL DAN PEMBAHASAN}

\section{Seleksi Sampel Penelitian}

Penelitian ini menggunakan data sekunder berupa laporan tahunan (annual report) perusahaan property, real estate, dan construction building yang terdaftar di Bursa Efek Indonesia periode 2012-2014. Setelah seleksi sampel dilakukan berdasarkan kriteria maka didapat sampel sebanyak 38 perusahaan yang dapat dijadikan sampel penelitian.

\section{Statistik Deskriptif}

Variabel ETR mempunyai nilai mean sebesar 0,2186 atau sebesar 21,86\%. Dari hal ini terlihat bahwa sebagian perusahaan property, real estate dan construction building yang terdaftar di BEI yang menjadi sampel penelitian ini telah menjalankan kewajiban perpajakan badannya sesuai dengan tarif yang ditentukan oleh Ditjen Pajak. Namun, apabila dilihat dari rentang nilai minimum dan nilai maksimum yaitu sebesar 0,04 sampai 0,75 terlihat bahwa masih ada perusahaan yang membayar pajak di bawah tariff yang ditentukan oleh Ditjen Pajak.

\section{Uji Asumsi Klasik}

\section{Uji normalitas}

Pada uji normalitas yang dilakukan pada semua variabel memiliki hasil nilai asymp sig (2-tailed) kecil dari alpha 0,05 yang berarti semua variabel yang digunakan dalam penelitian ini masih belum berdistribusi normal. Hasil pengujian normalitas dapat dilihat pada tabel 1 . 
Setelah itu dilakukan transform data pada uji normalitas dan didapatkan hasil nilai asymp sig (2-tailed) dari variabel tax avoidance, proporsi dewan komisaris, ROA dan karakter eksekutif besar dari alpha 0,05, dapat disimpulkan bahwa keempat berdistribusikan normal. Tetapi variabel komite audit masih belum berdistribusi normal dan pada variabel kualitas audit tidak dilakukan transform data karena merupakan variabel dummy. Hasil pengujian normalitas setelah transform data dapat dilihat pada tabel 2 .

Karena masih ada data yang tidak normal maka dilakukan pengujian normalitas dengan cara unstandardized residual. Setelah pengujian dilakukan dengan unstandardized residual maka didapat nilai asymp sig (2tailed) sebesar 0,76 dan nilainya lebih besar dari alpha 0,05. Maka dapat disimpulkan unstandardized residual berdistribusi normal.
Hasil uji normalitas menggunakan unstandardized residual dapat dilihat dalam tabel 3.

\section{Uji multikolinearitas}

Dari tiap-tiap variabel independen yang digunakan telah memiliki nilai VIF di bawah 10 dan nilai tolerance di atas 0,10 . Oleh sebab itu, dapat disimpulkan bahwa tiap-tiap variabel independen yang digunakan pada penelitian ini bebas dari multikolinearitas. Hasil pengujian multikolinearitas dapat dilihat pada tabel 4.

\section{Uji heteroskedastisitas}

Dilihat dari probabilitas pada hasil uji heteroskedastisitas menunjukan bahwa nilai probabilitas pada masing-masing variabel berada di atas alpha 0,05 yang berarti masingmasing variabel penelitian tersebut tidak terjadi heteroskedastisitas. Hasil pengujian heteroskedastisitas dapat dilihat pada tabel 5.

Tabel 1: Hasil Pengujian Normalitas (Sebelum Normal) One-Sample Kolmogorov-Smirnov Test

\begin{tabular}{lcccccc}
\hline & ETR & PDKI & KLT & KMT & ROA & RISK \\
\hline Kolmogorov-Smirnov Z & 2,083 & 3,602 & 4,875 & 5,198 & 1,738 & 2,545 \\
Asymp. Sig. (2-tailed) & 0,000 & 0,000 & 0,000 & 0,000 & 0,005 & 0,000 \\
\hline
\end{tabular}

Sumber: Hasil Pengolahan Data dengan SPSS 16.0

Tabel 2: Hasil Pengujian Normalitas Setelah Transform Data One-Sample Kolmogorov-Smirnov Test

\begin{tabular}{lcccccc}
\hline & Ln_ETR & Ln_PDKI & KLT & Ln_KMT & Ln_ROA & Ln_RISK \\
\hline Kolmogorov-Smirnov Z & 0,992 & 3,791 & 4,875 & 4,989 & 1,058 & 1,308 \\
Asymp. Sig. (2-tailed) & 0,278 & 0,070 & 0,000 & 0,000 & 0,213 & 0,065 \\
\hline
\end{tabular}

Sumber: Hasil Pengolahan Data dengan SPSS 16.0

Tabel 3: Hasil Pengujian Normalitas (Sesudah Normal) One-Sample Kolmogorov-Smirnov Test

\begin{tabular}{lc}
\hline & unstandardized residual \\
\hline Kolmogorov-Smirnov Z & 0,992 \\
Asymp. Sig. (2-tailed) & 0,278 \\
\hline
\end{tabular}

Sumber : Hasil Pengolahan Data dengan SPSS 16.0

Tabel 4: Hasil Pengujian Multikolinearitas

\begin{tabular}{lccccc}
\hline & Ln_PDKI & KLT & Ln_KMT & Ln_ROA & Ln_RISK \\
\hline Tolerance & 0,875 & 0,919 & 0,990 & 0,457 & 0,440 \\
VIF & 1,143 & 1,088 & 1,010 & 2,188 & 2,273 \\
\hline
\end{tabular}

Sumber: Hasil Pengolahan Data dengan SPSS 16.0

Tabel 5: Hasil Pengujian Heteroskedastisitas

\begin{tabular}{cccccc}
\hline & Ln_PDKI & KLT & Ln_KMT & Ln_ROA & Ln_RISK \\
\hline Sig. & 0,091 & 0,052 & 0,322 & 0,987 & 0,844 \\
\hline
\end{tabular}

Sumber: Hasil Pengolahan Data dengan SPSS 16.0 
Tabel 6: Pengujian Autokorelasi

\begin{tabular}{cccccc}
\hline Model & $\mathrm{R}$ & R-Square & Adjusted R Square & Std. Error of the Estimate & Durbin-watson \\
\hline 1 & $0,719^{\mathrm{a}}$ & 0,517 & 0,495 & 0,41574 & 1,961
\end{tabular}

Sumber: Hasil Pengolahan Data dengan SPSS 16.0

Tabel 7: Hasil Pengujian Regresi Linear Berganda

\begin{tabular}{cccccc}
\hline Model & \multicolumn{2}{c}{ Unstandardized Coefficient } & Unstandardized Coefficient & T & Sig. \\
\hline & B & Std. Error & Beta & & \\
\hline 1 (Constant) & $-4,151$ & 1,254 & & $-3,310$ & 0,001 \\
Ln_PDKI & $-2,72$ & 0,171 & $-0,114$ & $-1,589$ & 0,115 \\
KLT & 0,70 & 0,091 & 0,054 & 0,769 & 0,444 \\
Ln_KMT & $-0,015$ & 0,229 & $-0,004$ & $-0,065$ & 0,948 \\
Ln_ROA & $-0,736$ & 0,078 & $-0,928$ & 9,380 & 0,000 \\
Ln_RISK & $-0,356$ & 0,098 & 0,365 & 3,618 & 0,000 \\
\hline
\end{tabular}

Sumber: Hasil Pengolahan Data dengan SPSS 16.0

\section{Ujia utokorelasi}

Nilai Durbin-Watson (DW) yang dihasilkan adalah sebesar 1,961. Hasil yang diperoleh pada pengolahan data menunjukan hasil 1,792 $<1,961<2,208$ sehingga dapat disimpulkan bahwa model regresi yang akan dibentuk tidak terdeteksi gejala autokorelasi sehingga tahapan pengolahan data lebih lanjut dapat dilaksanakan. Hasil pengujian autokorelasi dapat dilihat pada tabel 6 .

\section{Analisis Regresi Linear Berganda}

Analisis regresi yaitu suatu metode analisa yang digunakan untuk menentukan ketepatan prediksi dari pengaruh yang terjadi antara variabel independen terhadap variabel dependen (Ghozali 2013).

Model yang digunakan dalam analisis ini terdiri dari dua persamaan regresi yang akan digunakan untuk menguji hubungan antara variabel-variabel independen dan masingmasing variabel dependen. Hasil pengujian regresi linear berganda dapat dilihat pada tabel 7 . Persamaan tersebut adalah sebagai berikut:

ETR $=-4,151-0,272$ PDKI + 0,070 KLT $0,015 \mathrm{KMT}-0,735 \mathrm{ROA}+0,356 \mathrm{RISK}+\mathrm{e}$

Keterangan:

ETR = Tax Avoidance

$\beta_{\mathrm{o}} \quad=$ Konstanta

$\beta_{1}-\beta_{5}=$ Koefisien Regresi Variabel

$P D K I=$ Proporsi Dewan Komisaris

$K L T=$ Kualitas Audit

$K M T=$ Komite Audit

ROA = Return on Assets

RISK = Karakter Eksekutif

$\mathrm{e}=$ error

\section{Pengujian Hipotesis}

Tabel 8: Tabel Hasil Uji Hipotesis

\begin{tabular}{lccccc}
\hline Model & \multicolumn{2}{c}{ Unstandardized Coefficients } & Unstandardized Coefficients & T & Sig. \\
& B & Std. Error & Beta & & \\
\hline (Constant) & $-4,151$ & 1,254 & & $-3,310$ & 0,001 \\
Ln_PDKI & $-0,272$ & 0,171 & $-0,114$ & $-1,589$ & 0,115 \\
KLT & 0,070 & 0,091 & 0,054 & 0,769 & 0,444 \\
Ln_KMT & $-0,015$ & 0,229 & $-0,004$ & $-0,065$ & 0,948 \\
Ln_ROA & $-0,736$ & 0,078 & $-0,928$ & $-9,380$ & 0,000 \\
Ln_RISK & 0,356 & 0,098 & 0,365 & 3,618 & 0,000 \\
\hline R Square & & & 0,517 & \\
\hline Adjusted R Square & & & 0,495 & \\
\hline F & & & 23,145 & \\
\hline Sig.
\end{tabular}

Sumber: Hasil Pengolahan Data dengan SPSS 16.0 


\section{Uji Koefisien Determinasi $\left(\mathbf{R}^{2}\right)$}

Berdasarkan hasil pengolahan dari tabel 8, besarnya pengaruh proporsi dewan komisaris independen, kualitas audit, komite audit, ROA, dan karakter eksekutif berpengaruh terhadap tax avoidance ditunjukan oleh nilai Adjusted $R$ square sebesar 0,495. Artinya variabel proporsi dewan komisaris independen, kualitas audit, komite audit, ROA, dan karakter eksekutif berpengaruh terhadap tax avoidance sebesar $49,5 \%$ sisanya sebesar $50,5 \%$ dipengaruhi oleh faktor lain yang tidak termasuk dalam penelitian ini.

\section{Uji F Statistik}

Nilai f Statistik pada pengujian ini adalah sebesar 23,145 dengan probabilitas 0,000. Nilai probabilitas lebih kecil dibandingkan nilai alpha 0,05 sehingga dapat disimpulkan bahwa variabel independen secara simultan berpengaruh terhadap variabel dependen. Jadi, kerangka penelitian atau model penelitian dapat diterima (Fit).

\section{Uji t Statistik}

Hasil uji t statistic dapat dilihat pada tabel pengujian hipotesis di atas. Berikut hasil pengujian hipotesis yang telah dilakukan.

\section{Pengaruh Proporsi Dewan Komisaris Independen Terhadap Tax Avoidance}

Berdasarkan pada hasil analisis data yang telah dilakukan, dapat dilihat bahwa variabel proporsi dewan komisaris independen memiliki nilai koefisien negatif dengan nilai $-1,589$ dan nilai probabilitas 0,115 (lebih besar dari 0,05). Hasil yang diperoleh tersebut menunjukan bahwa nilai probabilitasnya $0,115>$ 0,05 maka dapat disimpulkan bahwa proporsi dewan komisaris independen tidak berpengaruh signifikan terhadap tax avoidance.

\section{Pengaruh Kualitas Audit Terhadap Tax Avoidance}

Berdasarkan pada hasil analisis data yang telah dilakukan, dapat dilihat bahwa variabel kualitas audit memiliki nilai koefisien regresi positif dengan nilai 0,769 dan nilai probabilitas adalah 0,444 (lebih besar dari 0,05). Hasil yang diperoleh tersebut menunjukan bahwa nilai probabilitasnya $0,444>$ alpha 0,05 maka dapat disimpulkan bahwa kualitas audit tidak berpengaruh signifikan terhadap tax avoidance.

\section{Pengaruh Komite Audit Terhadap Tax Avoidance}

Berdasarkan pada hasil analisis data yang telah dilakukan, dapat dilihat bahwa komite audit memiliki nilai koefisien regresi negatif dengan nilai $-0,065$ dan nilai probabilitas adalah 0,948 (lebih besar dari 0,05). Hasil yang diperoleh tersebut menunjukan bahwa nilai probabilitas $0,948>$ alpha 0,05 maka dapat disimpulkan bahwa komite audit tidak berpengaruh signifikan terhadap tax avoidance. Hasil penelitian ini sesuai dengan penelitian yang dilakukan Prakosa (2014) yang menyatakan bahwa komite audit tidak berpengaruh terhadap tax avoidance.

\section{Pengaruh Return on Assets Terhadap Tax Avoidance}

Berdasarkan pada hasil analisis data yang telah dilakukan, dapat dilihat bahwa variabel ROA memiliki nilai koefisien regresi negatif dengan nilai $-9,380$ dan nilai probabilitas adalah 0,000 (lebih kecil dari 0,05). Hasil yang diperoleh tersebut menunjukan bahwa nilai probabilitasnya $0,000<$ alpha 0,05 maka dapat disimpulkan bahwa return on asset berpengaruh signifikan terhadap tax avoidance.

\section{Pengaruh Karakter Eksekutif Terhadap Tax Avoidance}

Berdasarkan pada hasil analisis data yang telah dilakukan, dapat dilihat bahwa variabel karakter eksekutif memiliki nilai koefisien regresi positif dengan nilai 3,618 dan nilai probabilitas adlah 0,000 (lebih kecil dari 0,05). Hasil yang diperoleh tersebut menunjukan bahwa karakter eksekutif berpengaruh signifikan terhadap tax avoidance. 


\section{SIMPULAN}

Berdasarkan hasil analisis dan pembahasan hasil pengujian hipotesis yang telah dilakukan, maka dapat disimpulkan hasil penelitian yang merupakan pemecahan masalah yang diajukan dalam penelitian ini adalah sebagai berikut: 1) Ditemukan bahwa proporsi dewan komisaris independen tidak berpengaruh signifikan terhadap tax avoidance, hal itu disebabkan dewan komisaris independen yang berasal dari luar perusahaan menuntut manajemen bekerja lebih efektif dalam pengelolaan perusahaan oleh direksi dan manajer. 2) Ditemukan bahwa kualitas audit tidak berpengaruh signifikan terhadap tax avoidance, hal ini disebabkan kualitas audit yang tinggi dapat mengurangi praktik penghindaran pajak. 3) Ditemukan bahwa komite audit tidak berpengaruh signifikan terhadap tax avoidance, hal ini komite audit yang merupakan bagian dari perseroan mempunyai tugas untuk melakukan pengawasan dan pengevaluasian terhadap kinerja operasional perusahaan tidak berjalan dengan baik. 4) Ditemukan bahwa return on assets berpengaruh signifikan terhadap tax avoidance, hal ini menunjukan kemampuan dari modal yang diinvestasikan secara keseluruhan aktiva mampu menghasilkan laba dan mengatur pendapatan dan pembayaran pajak. 5) Ditemukan bahwa karakter eksekutif berpengaruh signifikan terhadap tax avoidance, hal ini semakin eksekutif bersifat risk taker maka akan semakin tinggi tingkat penghindaran pajak.

\section{Keterbatasan dan Saran}

Peneliti menyadari bahwa penelitian yang telah dilakukan ini masih banyak memiliki kekurangan atau kelemahan, kondisi tersebut dikarenakan adanya sejumlah keterbatasan yang peneliti miliki. Secara umum keterbatasan tersebut adalah: 1) Penelitian ini hanya menggunakan data dengan jangka waktu pengamatan selama 3 tahun. Disarankan agar penelitian selanjutnya menambah jangka waktu pengamatan agar hasil yang didapatkan bias lebih akurat dan lebih efisien. 2) Penelitian ini hanya menggunakan tiga proksi dari CG dan satu dari profitabilitas serta satu dari risiko perusahaannya karakter eksekutif. Untuk penelitian selanjutnya disarankan agar menggunakan ataupun menambah proksi-proksi lain dari CG dan profitabilitas. 3) Penelitian ini hanya menggunakan sektor property, real estate, dan building construction. Penelitian selanjutnya diharapkan menggunakan perusahaan di sektor-sektor lain yang terdaftar di Bursa Efek Indonesia (BEI).

\section{DAFTAR REFERENSI}

Annisa, N. A., dan L. Kurniasih. 2012. Pengaruh corporate governance terhadap tax avoidance. Jurnal Akuntansi dan Auditing 8 (2): 95-189.

Berpotensi Lakukan Penghindaran Pajak 40\% Pengembang Real Estate Perlu Diperiksa 2015. www.finance.detik.com (accessed April 27, 2015).

Budiman, J., dan Setiyono. 2012. Pengaruh karakter eksekutif terhadap penghindaran pajak (Tax avoidance). Skripsi., Universitas Islam Sultan Agung.

Desai, M. A, dan D. Dharmapala. 2005. Corporate tax avoidance and firm value. Journal of Financial Economics 91 (3): 537-546.

Dewi, N.Y.K, dan I. K. Jati. 2014. Pengaruh karakter eksekutif, karakteristik perusahaan, dan dimensi tata kelola perusahaan yang baik pada tax avoidance di Bursa Efek Indonesia. E-Journal Akuntansi Universitas Udayana 6 (2): 249-260.

Dirjen Pajak. 2014. Mengenal Penghindaran Pajak (Tax Avoidance). http://www.pajak.go.id/content/article/ mengenal-penghindaran-pajak-taxavoidance (diakses 27 Maret 2015).

Dyreng, S. D., M. Hanlon, dan E.L. Maydew. 2010. The Effect of executive on corporate tax avoidance. The Accounting Review 85 (14): 1163-1189.

Ghozali, I. 2013. Aplikasi analisis multivariate dengan program IBM SPSS 21. 
Semarang: Badan Penerbit Universitas Diponegoro.

Hutagaol, J. 2007. Perpajakan: Isu-isu kontemporer. Yogyakarta: Graha Ilmu.

Jensen, M. C., dan W. H. Meckling. 1976. Theory of the firm: Managerial behavior, agency costs and ownership structure." Journal of Financial Economics 3 (4): 305-360.

Lewellen, K. 2006. Financing decisions when managers are risk averse. Journal of Financial Economics 82 (3): 551-89.

Low, A. 2009. Managerial risk taking behavior and equity-based compensation. Journal of Financial Economics 92 (3): 470-90.

Maharani, I. G. A., dan K. A. Suardana. 2014. Pengaruh corporate governance, profitabilitas, dan karakteristik eksekutif pada tax avoidance perusahaan manufaktur. E-Journal Akuntansi Universitas Udayana 9 (2): 525-539.

Mangoting, Y. 1999. Tax planning: Sebuah pengantar sebagai alternatif meminimalkan pajak. Jurnal Akuntansi dan Keuangan 1 (1): 43-53.

Meilinda, M., dan N. Cahyonowati. 2013. Pengaruh corporate governance terhadap pajak. Journal of Accounting
2 (3): 559-571.

Pohan, H. T. 2009. Analisis pengaruh kepemilikan institusi, ratio Tobin Q, akrual pilihan, tarif efektif pajak dan biaya pajak ditunda terhadap penghindaran pajak pada perusahaan publik. Jurnal Informasi, Perpajakan, Akuntansi dan Keuangan Publik 4 (2): 113-135

Prakosa, K. B. 2014. Pengaruh profitabilitas, kepemilikan keluarga, dan corporate governance terhadap penghindaran pajak di Indonesia. SNA 17 Mataram, Lombok.

Pranata, F. M. 2014. Pengaruh karakter eksekutif dan corporate governance terhadap tax avoidance. Skripsi., Universitas Bung Hatta, Padang.

Sekaran, U. 2011. Research methods for bussines. Jakarta: Salemba Empat.

Sugiyono. 2013. Statistik untuk penelitian. Bandung: Alfabeta.

Winata, F. 2014. Pengaruh corporate governance terhadap tax avoidance pada perusahaan yang terdaftar di Bursa Efek Indonesia tahun 2013. Tax \& Accounting Review 4 (1): 1-11.

Waluyo. 2011. Perpajakan Indonesia. Jakarta: Salemba Empat. 